\title{
HUMAN CAPITAL APPROACH TO INCREASING PRODUCTIVITY OF HUMAN RESOURCES MANAGEMENT
}

\author{
Iwan Sukoco* dan Dea Prameswari** \\ *Department of Business Administration Science \\ **Graduate Business Administration Science \\ Faculty of Social and Political Science, Padjadjaran University \\ Email:iwan.sukoco@unpad.ac.id,dprdea@gmail.com
}

\begin{abstract}
This paper discusses the human capital approach to manage human resources becoming more productive. The method used in this research is qualitative method with descriptive research. Human capital approach for the implementation has five main components, namely individual capability, individual motivation, the organization climate, workgroup effectiveness and leadership. Recognizing the importance of the role of human resources in the activities of the company, then the company should manage human resources as best as possible because the key to success of a company is not only the benefits of technology and the availability of funds, but also on the human factor. Based on observations in Indonesia, there are still many companies that have not implemented the most optimal approach to human capital. The results of the study indicate that the human capital component is not yet optimal, especially in terms of individual capability and individual motivation.
\end{abstract}

Keywords : Human capital approach, individual capability, individual motivation, the organization climate, workgroup effectiveness and leadership

\section{PENDEKATAN HUMAN CAPITAL UNTUK PENGELOLAAN SUMBER DAYA MANUSIA YANG LEBIH PRODUKTIF}

\begin{abstract}
ABSTRAK
Tulisan ini membahas pendekatan human capital untuk mengelola sumber daya manusia yang lebih produktif. Metode yang digunakan dalam penelitian ini adalah metode kualitatif dengan jenis penelitian deskriptif. Pendekatan human capital menerapkan lima komponen utama, yaitu individual capability, individual motivation, the organization climate, workgroup effectiveness dan leadership. Menyadari pentingnya peran sumber daya manusia dalam kegiatan perusahaan, maka hendaknya perusahaan perlu mengelola sumber daya manusia sebaik mungkin karena kunci sukses suatu perusahaan bukan hanya pada keunggulan teknologi dan tersedianya dana, melainkan juga pada faktor manusianya. Berdasarkan pengamatan masih banyak perusahaan di Indonesia yang belum menerapkan pendekatan human capital secara optimal. Hasil penelitian mengindikasikan bahwa penerapan komponen human kapital belum optimal terutama pada aspek individual capability dan individual motivation.
\end{abstract}

Kata kunci : Pendekatan human capital, individual capability, individual motivation, the organization climate, workgroup effectiveness and leadership 


\section{PENDAHULUAN}

Sumber daya perusahaan adalah semua faktor baik sumber daya yang berwujud (tangible asset) maupun yang tidak berwujud (intangible asset). Human capital merupakan salah satu komponen utama dari intangible asset yang dimiliki perusahaan. Namun selama ini biasanya penilaian terhadap kinerja perusahaan lebih banyak menggunakan sumber daya yang bersifat tangible asset.

Dengan demikian human capital bukanlah memposisikan manusia sebagai modal layaknya mesin sehingga seolah-olah manusia sama dengan mesin. Namun human capital justru bisa membantu pengambil keputusan untuk memfokuskan pembangunan manusia dalam rangka peningkatan mutu organisasi. Oleh karena itu perusahaan harus dapat melakukan peningkatan kualitas sumber daya manusia dalam menghadapi tantangan, dan juga untuk mencapai visi dan misi perusahaan.

Human capital management merupakan pengembangan baru dari human resource management, dimana perbedaannya adalah pada filosofi mendasar yang melekat pada kedua pendekatan tersebut. Pendekatan human capital merupakan suatu pemikiran yang menganggap bahwa manusia merupakan suatu bentuk capital atau barang modal sebagaimana barang-barang modal lainnya dan atau sebagai asset perusahaan. Pengertian human capital menekankan pada pengertian bahwa manusia merupakan salah satu modal utama dalam perusahaan dengan nilai dan jumlah yang tidak terhingga, yang dapat dikelola dalam suatu proses, yang pada akhirnya dapat menghasilkan value yang lebih bagi perusahaan.

Pada human resource, manusia dianggap sebagai sumber daya. Dengan pengertian tersebut perusahaan beranggapan bahwa manusia dapat habis apabila dieksploitasi secara berlebihan. Dengan dasar pengertian ini pula, banyak perusahaan yang mengartikan bahwa pengadaan dan pemeliharaan sumber daya manusia memerlukan biaya yang tidak sedikit, namun perusahaan tidak memperoleh banyak manfaat yang sepadan dari padanya.

Menurut Larkan (2008:57), "Human capital lahir didasari oleh fenomena bahwa pada abad 21 ini kesadaran manajemen perusahaan dalam pengelolaan SDM semakin tinggi. Perusahaanperusahaan mulai menyadari bahwa kinerja perusahaan bukan hanya ditentukan oleh capital yang berupa finansial, mesin, teknologi, dan modal tetap, melainkan terutama dipengaruhi oleh intangible capital, yaitu sumber daya manusia (SDM)".

Sekarang ini banyak perusahaan di Indonesia yang sudah memulai mengganti nama bagian, divisi atau departemen human resource management menjadi bagian, divisi atau departemen human capital management. Masalahnya apakah penggantian nama atau istilah tersebut memang sudah benar-benar dipahami sehingga filosofi pendekatan human capital tersebut dan penerapaannya sudah sesuai atau penggantian tersebut hanya sekedar ganti namaya saja, sementara isi dan penerapanya tidak berubah. Atas dasar tersebut, penulis tertarik untuk meneliti penerapan human capital tersebut pada PT X.

\section{TINJAUAN PUSTAKA}

\section{Definisi Human Capital}

Human Capital diartikan sebagai manusia itu sendiri yang secara personal dipinjamkan kepada perusahaan dengan kapabilitas individunya, komitmen, pengetahuan, dan pengalaman pribadi. Walaupun tidak sematamata dilihat dari individual tapi juga sebagai tim kerja yang memiliki hubungan pribadi baik di dalam maupun luar perusahaan (Stewart 1997 dalam Totanan 2004).

Menurut Malhotra dan Bontis (dalam Rachmawati dan Wulani, 2004), Human capital merupakan kombinasi dari pengetahuan, 
keterampilan, inovasi dan kemampuan seseorang untuk menjalankan tugasnya sehingga dapat menciptakan suatu nilai untuk mencapai tujuan. Pembentukan nilai tambah dikontribusikan oleh human capital dalam menjalankan tugasnya akan memberikan Suistanable Revenue di masa yang akan datang bagi suatu perusahaan tersebut.

Human capital merupakan nilai tambah bagi perusahaan dalam perusahaan setiap hari, melalui motivasi, komitmen, kompetensi, serta efektivitas kerja tim, nilai tambah yang dapat dikontribusikan oleh pekerja berupa: pengembangan kompetensi yang dimiliki oleh perusahaan, pemindahan pengetahuan dari pekerja ke perusahaan serta perubahan budaya manajemen (Mayo 2000 dalam Rachmawati et al.2004). Andrew Mayo dalam Ongkodihardjo (2008:40) mendefinisikan "human capital sebagai kombinasi warisan genetik, pendidikan, pengalaman, dan perilaku tentang hidup dan bisnis".

Berdasarkan pendapat di atas, dapat disimpulkan bahwa human capital merupakan segala sesuatu mengenai manusia dengan segala kapabilitas yang dimilikinya, sehingga dapat menciptakan nilai bagi organisasi untuk mencapai tujuan.

\section{Konsep Human Capital}

Menurut Jac Fitz-enZ (2009:45), Human capital muncul akibat dari pergeseran peran sumber daya manusia dalam organisasi dari sebagai beban menjadi asset/modal. Konsep human capital menggagas nilai tambah yang dapat diberikan oleh karyawan (manusia) kepada organisasi tempat mereka bekerja. Chatzkel menyatakan bahwa human capital-lah yang menjadi faktor pembeda dan basis aktual keunggulan kompetitif organisasi. Teori human capital, sebagaimana dinyatakan oleh Ehrenberg dan Smith, mengkonseptualkan bahwa karyawan memiliki serangkaian keterampilan yang dapat "disewakan" kepada organisasi mereka.
Menurut Larkan (2008:57), Human capital lahir didasari oleh fenomena bahwa pada abad 21 ini kesadaran manajemen perusahaan dalam pengelolaan SDM semakin tinggi. Perusahaanperusahaan mulai menyadari bahwa kinerja perusahaan bukan hanya ditentukan oleh capital yang berupa finansial, mesin, teknologi, dan modal tetap, melainkan terutama dipengaruhi oleh intangible capital, yaitu Sumber Daya Manusia (SDM).

Seperti dideskripsikan oleh Scarborough dan Elias (2009:61), konsep human capital sebaiknya dipandang sebagai jembatan yaitu mendefinisikan hubungan antara praktik manajemen SDM dengan kinerja bisnis. Mereka menunjukkan bahwa human capital memiliki definisi yang dinamis, implisit, tidak baku, dan kontekstual. Karakteristik ini membuat human capital sulit di evaluasi. Ciri human capital yang sangat penting bagi kinerja perusahaan adalah keluwesan dan kreativitas individu, kemampuan mereka untuk mengembangkan keterampilan seumur hidup, dan merespons berbagai konteks situasi. Mereka menyebutkan bahwa acuan teori human capital adalah manusia dan keterampilan, sementara acuan teori physical capital adalah pabrik dan peralatan.

Manusia sebagai pelaku bisnis memiliki etos kerja produktif, keterampilan, kreativitas, disiplin, profesionalisme, serta memiliki kemampuan memanfaatkan, mengembangkan dan menguasai IPTEK maupun kemampuan manajemen. Dalam kehidupan yang nyata manusia memegang peranan utama dalam meningkatkan produktifitas dan alat produksi yang canggih serta dituntut menjadi sumber daya manusia (SDM) yang terampil / ahli. Keberhasilan suatu organisasi sangat dipengaruhi oleh kinerja individu karyawan.

Human capital merupakan karakteristik sumber daya manusia (SDM) yang ditentukan oleh pengetahuan yang dimiliki yang digunakan untuk menciptakan nilai bagi organisasi (Collin and Clark, 2003:61). Creating value (menciptakan nilai) adalah upaya penciptaan 
nilai melalui membangun kapabilitas, penguatan arah strategi bisnis, dan mengutamakan peluang istemewa untuk mewujudkan keunggulan daya saing oraganisasi (Ingham:2007:34). Hasil studi Penning et al (1998:10) menjelaskan bahwa manajemen human capital harus memperhatikan sumber-sumber pengetahuan dan aliran pengetahuan-pengetahuan tersebut. Aliran pengetahuan dimaksudkan sebagai proses perkembangan keahlian dan pelembagaan pengetahuan.

Dalam buku ROI of Human Capital Jac FitzenZ (2009:45) mengungkapkan dorongan untuk mengukur human capital ini merefleksikan perubahan peran manajemen sumber daya manusia dari peran administratif menjadi partner bisnis yang strategis. Lebih lanjut dikatakan orang semakin menyadari bahwa sumber keunggulan bersaing bukan berasal dari desain produk atau layanan yang canggih, strategi pemasaran yang terbaik, desain teknologi, atau manajemen keuangan yang paling cerdas, tetapi berasal dari adanya sistem yang tepat, aktivitas memotivasi, dan mengelola organisasi sumber daya manusia.

Konsep human capital muncul karena adanya pergeseran peranan sumber daya manusia. Human capital muncul dari pemikiran bahwa manusia merupakan intangible asset yang memiliki banyak kelebihan yaitu:

1. Kemampuan manusia apabila digunakan dan disebarkan tidak akan berkurang melainkan bertambah baik bagi individu yang bersangkutan maupun bagi organisasi.

2. Manusia mampu mengubah data menjadi informasi yang bermakna

3. Manusia mampu berbagi intelegensia dengan pihak lain.

Menurut Derek Stokey (2003:41) perlunya human capital pada masa sekarang berdasarkan pada:

1. Kuatnya tekanan persaingan keuntungan finansial dan nonfinansial
2. Pemimpin bisnis dan politik mulai mengakui bahwa memiliki orang yang skill dan motivasi tinggi dapat memberikan perbedaan peningkatan kinerja yang signifikan

3. Terjadi perubahan yang cepat yang ditandai adanya proses dan teknologi yang baru tidak akan bertahan lama apabila pesaing mampu mengadopsi teknologi yang sama. Namun untuk mengimplementasikan perubahan, tenaga kerja yang dimiliki industri harus memiliki skill dan kemampuan yang lebih baik.

4. Untuk tumbuh dan beradaptasi, kepemimpinan organisasi harus mengenali nilai dan kontribusi manusia.

Konsep utama dari human capital menurut Becker (1993:71) adalah bahwa manusia bukan sekedar sumber daya namun merupakan modal (capital) yang menghasilkan pengembalian (return) dan setiap pengeluaran yang dilakukan dalam rangka mengembangkan kualitas dan kuantitas modal tersebut merupakan kegiatan investasi. Pada saat mengoptimalkan dan mengukur Return On Investment (ROI) pada human capital, perlu memahami bagaimana hal tersebut berinteraksi dengan bentuk capital lainnya, baik yang berwujud maupun yang tidak berwujud. HC ROI merupakan sejumlah benefit yang diperoleh organisasi atau tingkat pengembalian / profitabilitas dari sejumlah uang yang dikeluarkan untuk membiayai tenaga kerja.

\section{Komponen Human Capital}

Menurut Andrew Mayo (2000) dalam Ongkodihardjo (2008:41) bahwa :

"Human Capital memiliki lima komponen yang memiliki peranan yang berbeda dalam menciptakan human capital perusahaan yang pada akhirnya menentukan nilai sebuah perusahaan. Kelima komponen Human Capital tersebut adalah individual capability, individual motivation, the organization climate, workgroup effectiveness dan leadership". 


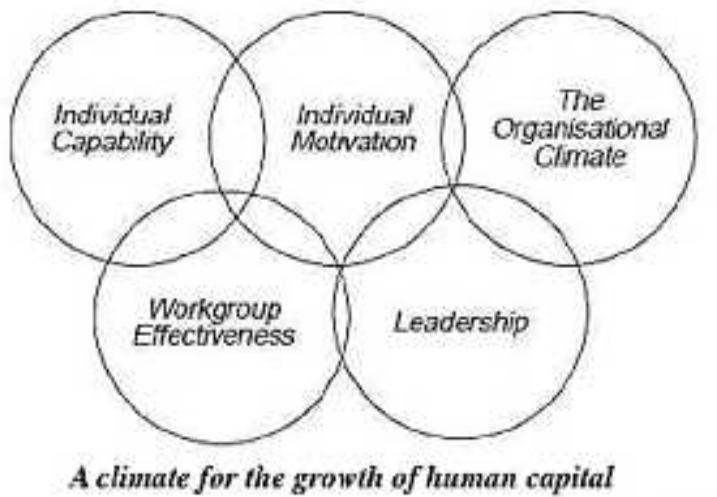

Gambar 1. Komponen Human Capital (Andrew Mayo)

\section{Individual Capability}

Kecakapan individu dapat dibagi ke dalam dua bagian yaitu kecakapan nyata (actual ability) dan kecakapan potensial (potential ability). Kecakapan nyata yaitu kecakapan yang diperoleh melalui belajar (achievement atau prestasi), yang dapat segera didemonstrasikan dan diuji sekarang. Kecakapan potensial merupakan aspek kecakapan yang masih terkandung dalam diri individu dan diperoleh dari faktor keturunan. Kecakapan potensial dapat dibagi ke dalam dua bagian yaitu kecakapan dasar umum (intelligence atau kecerdasan) dan kecakapan dasar khusus (bakat dan atitudes).

Menurut Mayo (2000) individual capability meliputi lima kriteria, yaitu:

1) Personal capabilities, yaitu kemampuan yang dimiliki oleh seseorang dari dalam dirinya sendiri, meliputi penampilan, pikiran, tindakan, dan perasaannya.

2) Profesional andtechnical khow-how, yaitu kemampuan untuk bersikap profesional dalam setiap situasi dan kondisi serta adanya kemauan untuk melakukan transfer knowledge dari yang senior ke junior.

3) Experience, yaitu seseorang yang berkompeten dan memiliki pengalaman yang sudah cukup lama di bidangnya serta memiliki sikap terbuka terhadap pengalaman.
4) The network and range of personal contacts, yaitu seseorang dikatakan berkompeten apabila memiliki jaringan atau koneksi yang luas dengan siapa saja terutama orang-orang yang berhubungan dengan profesinya

5) The value and attitudes that influence actions, yaitu nilai dan sikap akan mempengaruhi tindakannya di dalam lingkungan kerja seperti memiliki kestabilan emosi, ramah, dapat bersosialisasi, dan tegas.

\section{Individual Motivation}

Menurut Anwar Prabu Mangkunegara (2008:61), "Motivasi merupakan kondisi atau energi yang menggerakkan diri karyawan yang terarah atau tertuju untuk mencapai tujuan organisasi perusahaan".

Motivasi terbentuk dari sikap (attitude) karyawan dalam menghadapi situasi kerja di perusahaan. Sikap mental karyawan yng positif terhadap situasu kerja itulah yang memperkuat motivasi kerjanya untuk mencapau kinerja yang maksimal. Sikap mental karyawan haruslah memiliki sikap mental yang siap sedia secara psikofisik (siap secara mental, fisik, situasi, dan tujuan). Artinya, karyawan dalam bekerja secara mental siap, fisik sehat, memahami situasi, dan kondisi serta berusaha keras mencapai target kerja (tujuan utama organisasi).

Motivasi dalam berprestasi dapat diartikan sebagai suatu dorongan dalam diri seseorang untuk melakukan atau mengerjakan suatu kegiatan atau tugas dengan sebaik-baiknya agar mencapai prestasi. Edward Murray (2008:62) berpendapat bahwa karakteristik orang yang mempunyai motivasi berprestasi tinggi adalah sebagai berikut:

1. Melakukan sesuatu dengan sebaik-baiknya

2. Melakukan sesuattu dengan mencapai kesuksesan

3. Menyelesaikan tugas-tugas yang memerlukan usaha dan keterampilan

4. Berkeinginan menjadi orang terkenal dan menguasai bidang tertentu 
5. Melakukan hal yang sukar dengan hasil yang memuaskan

6. Mengerjakan sesuatu yang sangat berarti

7. Melakukan sesuatu yang lebih baik daripada orang lain

\section{The Organization Climate}

Budaya organisasi adalah sistem nilai organisasi yang dianut oleh anggota organisasi, yang kemudian mempengaruhi cara bekerja dan berperilaku dari para anggota organisasi. Berdasarkan hasil riset dari C.O'Reily III, J.Rhatman dan D.F Caldwell (dalam Suwarto, 2009;4) dikemukakan tujuh karakteristik primer yang secara bersama-sama menangkap hakikat budaya suatu organisasi, yaitu sebagai berikut:

1. Inovasi dan pengambilan resiko (innovation and risk taking), sejauh mana karyawan didukung untuk menjadi inovatif dan mengambil resiko.

2. Perhatian terhadap detail. Sejauh mana karyawan diharapkan menunjukkan kecermatan, analisis dan perhatian terhadap detail.

3. Orientasi hasil. Sejauh mana manajemen memfokuskan pada hasil bukan pada teknik dan proses yang digunakan untuk mencapai hasil tersebut.

4. Orientasi orang. Sejauh mana keputusan manajemen memperhitungkan efek pada orang-orang di dalam organisasi itu.

5. Orientasi tim. Sejauh mana kegiatan kerja diorganisasikan sekitar tim-tim, bukan individu.

6. Keagresifan. Berkaitan dengan agresivitas karyawan.

7. Kemantapan. Organisasi menekankan dipertahankannya budaya organisasi yang sudah baik.

Suasana kerja yang kondusif akan mendorong karyawan untuk memberikan kontribusi yang maksimum kepada perusahaan. Karyawan yang merasa puas terhadap perusahaan tempat dia bekerja, kemungkinan besar akan memilih terus bekerja di tempat tersebut walaupun muncul peluang tawaran pekerjaan di tempat lain. Apabila karyawan sudah mempunyai keterikatan yang kuat dengan perusahaan, maka mereka akan bekerja keras demi perkembangan perusahaan.

\section{Workgroup Effectiveness}

Efektifitas tim kerja didasarkan pada dua hasil-hasil produktif dan kepuasan pribadi. Kepuasan berkenaan dengan kemampuan tim untuk memenuhi kebutuhan pribadi para anggotanya dan kemudian mempertahankan keanggotaan serta komitmen mereka. Hasil produktif berkenaan dengan kualitas dan kuantitas hasil kerja seperti yang didefinisikan oleh tujuan-tujuan tim yaitu konteks organisasional, struktur, strategi, lingkungan budaya, dan sistem penghargaan. Karakter tim yang penting adalah jenis, struktur, dan komposisi tim. Karakteristik-karakteristik tim ini mempengaruhi proses internal tim, yang kemudian mempengaruhi hasil dan kepuasan. Para pemimpin harus memahami dan mengatur tingkat-tingkat perkembangan, kekompakan, norma-norma, dan konflik supaya dapat membangun tim yang efektif.

Menurut Ali Muhammad Abdul (2004:89), "karakteristik tim kerja yang efektif ini memiliki tiga aspek dan dapat dijadikan standar efektivitas sebuah tim". Ketiga aspek tersebut adalah:

1) Aspek Internal

a. Definisi yang baik tentang tugas-tugas tim

b. Penetapan target jangka panjang dan periodik

c. Pembatasan masalah dan macammacamnya

d. Terdapat alternatif yang relevan

2) Aspek Manajerial
a. Persiapan yang baik
b. Persamaan yang matang
c. Penetapan standar-standar penilaian hasil
d. Kerangka-kerangka yang diikuti
e. Kepemimpinan yang baik bagi tim 
f. Pembuatan keputusan dengan kata sepakat bukan dengan aklamasi atau suara yang paling minim

3) Aspek Perilaku/Sosial

a. Keikutsertaan semua anggota dalam mendiskusikan masalah dan solusi penyelesaian

b. Menerima tugas yang dibebankan kepada anggota dan mempersiapkan diri untuk melaksanakannya dengan baik

c. Memberikan atensi dan kesadaran dan pemahaman kepada orang secara bijaksana

d. Mengungkapkan perasaan dan indra terhadap pemikiran dan pandangan

e. Kesadaran anggota dan pemahaman mereka terhadap masalah yang ada, kerangka penyelesaian, usaha-usaha pelaksanaan, kerjasama, pengorbanan, dan pemberian bantuan dan adanya polemik dan konflik kerangka kerja, bukan sekitar kepribadian.

\section{Leadership}

Menurut Tannebaum, Weschler and Nassarik (dalam Abdussalam 2008:18) kepemimpinan adalah pengaruh antar pribadi dalam situasi tertentu dan langsung melalui proses komunikasi untuk mencapai satu atau beberapa tujuan tertentu.

Sedangkan Shared Goal, Hemhiel \& Coons dalam abdussalam 2008:20) mengatakan "Kepemimpinan adalah sikap pribadi yang memimpin pelaksanaan aktivitas untuk mencapai tujuan yang diinginkan".

Selanjutnya beliau mengatakan, karakteristik seorang pemimpin didasarkan kepada prinsip-prinsip sebagai berikut:

1) Seseorang yang belajar seumur hidup

Seseorang belajar tidak hanya melalui pendidikan formal, tetapi juga diluar sekolah. Selain itu, mempunyai pengalaman yang baik maupun yang buruk sebagai sumber pembelajaran.
2) Berorientasi pada pelayanan

Seorang pemimpin tidak dilayani tetapi melayani sebab prinsip pemimpin dengan prinsip melayani berdasarkan karir sebagai tujuan utama. Dalam memberikan pelayanan, pemimpin seharusnya lebih berprinsip pada pelayanan yang baik.

3) Membawa energi yang positif

Dalam menggunakan energi yang positif didasarkan pada keihklasan dan keinginan mendukung kesuksesan orang lain. Untuk itu dibutuhkan energi positif untuk membangun hubungan baik. Seorang pemimpin harus dapat dan mau bekerja untuk jangka waktu yang lama dan dalam kondisi yang tidak ditentukan. Oleh karena itu, seorang pemimpin hrus dapat menunjukkan energi yang positif.

\section{METODE PENELITIAN}

Metode penelitian yang digunakan dalam penelitian ini adalah metode kualitatif dengan jenis deskriptif. Pengumpulan data menggunakan sumber primer dan sumber sekunder. Sumber primer adalah sumber data yang langsung memberikan data kepada pengumpul data, dan sumber sekunder merupakan sumber yang tidak langsung memberikan data kepada pengumpul data, misalnya lewat dokumen (Sugiyono, 2011: 225).

\section{HASIL DAN PEMBAHASAN}

\section{Penerapan Human Capital Management pada PT X}

Latar belakang perubahan human resources management menjadi human capital management pada PT X didasarkan pada paradigma bahwa human resources menganggap manusia sebagai sumber daya. Sedangkan pada human capital, manusia dianggap sebagai asset perusahaan. Hal ini didukung dengan pernyataan Ibu Yenny (Senior Vice President Human Capital \& Facilities Management) selaku informan utama, yang menyatakan bahwa: 
"PT X merupakan perusahaan jasa, sehingga yang menggerakkan industri ini adalah manusianya. Kalau di pabrik asset nya itu mesin, kalau di bank capital nya adalah uang. Saat ini manusia yang ada dalam perusahaan / para karyawan telah dianggap sebagai asset dan juga sebagai capital karena menjadi penggerak industri ini, bukan sebagai sumber daya yang di kemudian hari nilainya akan dapat habis bila digunakan secara terus-menerus."

Paradigma ini juga sejalan dengan latar belakang munculnya human capital yang dinyatakan oleh Larkan (2008:57) bahwa human capital lahir didasari oleh kesadaran manajemen perusahaan dalam pengelolaan SDM yang semakin tinggi. Perusahaan-perusahaan mulai menyadari bahwa kinerja perusahaan bukan hanya ditentukan oleh kapital yang berupa finansial, mesin, teknologi, dan modal tetap, melainkan terutama dipengaruhi oleh intangible capital, yaitu sumber daya manusia (SDM).

Perubahan human resource management menjadi human capital management pada PT X baru berlangsung sejak tahun 2014. Awal perubahannya, PT $\mathrm{X}$ mulai melihat bahwa manusia yang ada harus dikelola sebagai kapital. Berikut merupakan pernyataan Ibu Yenny:

"Di awal perubahan menjadi human capital management, kita mulai melihat bahwa human ini harus di touch sebagai capital.Setelah dianggap menjadi capital, maka harus ada gain nya dong. Gain tersebut diharapkan dapat berkembang secara positif sehingga harus ada investasi yang dilakukan terhadap asset perusahaan. Investasi yang dilakukan dalam mengelola manusia bersifat jangka panjang. Dimana kebermanfaatan dari investasi ini akan berdampak pada performance perusahaan (dapat dilihat dari kenaikan revenue, premi, dan juga awarding terhadap perusahaan)".

Konsep utama dari human capital menurut Becker (1993:71) yaitu manusia bukan sekedar sumber daya namun merupakan modal (capital) yang menghasilkan pengembalian (return) dan setiap pengeluaran yang dilakukan dalam rangka mengembangkan kualitas dan kuantitas modal tersebut merupakan kegiatan investasi. Dengan demikian, pengertian human capital menekankan pada pengertian bahwa manusia merupakan salah satu modal utama dalam perusahaan dengan nilai dan jumlah yang tidak terhingga, yang dapat dikelola dalam suatu proses, yang pada akhirnya dapat menghasilkan nilai tambah bagi perusahaan untuk dapat mencapai tujuan.

Tentunya pemeliharaan sumber daya manusia berbasis human capital ini memerlukan biaya yang tidak sedikit, namun hal tersebut tidak menjadi masalah bila dampak yang dapat diberikan yaitu sejumlah benefit yang diperoleh perusahaan atau tingkat pengembalian dari sejumlah uang yang dikeluarkan untuk membiayai pengelolaan tenaga kerja. Seperti yang dinyatakan oleh Becker bahwa setiap pengeluaran yang dilakukan dalam rangka mengembangkan kualitas dan kuantitas modal tersebut merupakan kegiatan investasi yang menghasilkan pengembalian (return).

Dalam pendekatan human capital, manusia memiliki peranan yang sangat penting selain modal (uang), sumber alam, teknologi dan proses produksi. Untuk mengembangkan sumber daya manusia yang berkualitas, tentunya ada beberapa hambatan yang tentu akan dihadapi. Adapun hambatan yang dialami oleh PT X saat berubahnya paradigma menjadi human capital adalah bagaimana membuat para karyawan menjadi kapital bagi perusahaan. Tantangannya adalah managemen harus memilih orang-orang yang tepat pada saat recruitment. Seleksi harus dilakukan dengan baik, jika tidak baik akan menjadi beban perusahaan.. Tantangan lainnya yaitu dalam hal mengembangkan karyawan menghadapi dilemma pembajakan (hijack). Segala upaya telah dilakukan oleh perusahaan untuk mengelola dan mengembangkan sumber daya manusianya, akan tetapi ada karyawan yang dibajak oleh perusahaan lain. Dengan sistem human capital management ini, perusahaan harus memperbaharui diri dalam menjalankan 
fungsi-fungsi sdm mulai dari proses recruitment sampai dengan termination.

Menurut Andrew Mayo (2000) dalam Ongkodihardjo (2008:41) bahwa :

"Human Capital memiliki lima komponen yang memiliki peranan yang berbeda dalam menciptakan human capital perusahaan yang pada akhirnya menentukan nilai sebuah perusahaan. Kelima komponen Human Capital tersebut adalah individual capability, individual motivation, the organization climate, workgroup effectiveness dan leadership".

Komponen pertama yaitu individual capability. Salah satu upaya perusahaan dalam pencapaian peningkatan kualitas sumber daya manusia adalah dengan merancang dan melakukan program pengembangan karyawan (people development) agar lebih sesuai dengan kebutuhan pekerjaan dan tujuan organisasi, sehingga optimalisasi kinerja karyawan akan tercapai sesuai keingingan perusahaan dan kebutuhan karyawan. Pengembangan tersebut akan menguntungkan organisasi dan individu. Pengembangan yang dilakukan diharapkan dapat meningkatkan kinerja karyawan.

People development management merupakan suatu proses bersama antara atasan dan karyawan yang bertujuan untuk memberikan kesempatan kepada karyawan untuk mengembangkan kompetensi dan karakternya sesuai dengan tuntutan pekerjaan dan kebutuhan perusahaan. Dengan ini diharapkan efektifitas pengembangan karyawan akan lebih tinggi serta karyawan yang bersangkutan dapat meningkatkan kinerjanya. Terdapat beberapa tahap yang perlu diperhatikan untuk memastikan bahwa people development management merupakan suatu program yang akan mendukung pertumbuhan perusahaan, antara lain:

1) Konsep Dasar

Konsep Dasar yang diterapkan oleh perusahaan yaitu konsep kompetensi dan juga talent.

2) Menyusun Competency Profile
PT X telah memiliki kamus kompetensi tersendiri. Pada dasarnya suatu model kompetensi memuat dua unsur yaitu Soft Skill dan Hard Skill.

3) Evaluasi Kompetensi Individu

Merupakan formulir yang berisi persyaratan kompetensi suatu posisi, penilaian kompetensi beserta kekuatan dan kelemahan yang dimiliki.

\section{4) Membuat Individual Performance Plan (IPP)}

Dokumen yang disusun bagi setiap karyawan yang berisi rencana karir karyawan tersebut selama 1 periode.

\section{5) Menyusun Individual Development Plan (IDP)}

Dokumen yang berisi rencana pengembangan kompetensi dan karakter karyawan. Dokumen ini disusun bersama oleh atasan dan karyawan yang bersangkutan. IDP merupakan hasil tindak lanjut dari evaluasi kompetensi individu.

6) Membuat Replacement Table Chart

Bagian ini mengidentifikasikan posisi-posisi penting, pengganti yang memungkinkan untuk pemangku jabatan di setiap posisi tersebut, baik apakah pengganti yang potensial itu saat ini telah mempunyai latar belakang untuk memikul tanggung jawab pekerjaan tersebut, ataukah pengganti potensial itu memerlukan sejumlah waktu yang diharapkan untuk siap memikul tanggung jawab tersebut.

Kesimpulan umum mengenai konsep People Development adalah dimana perusahaan memiliki suatu sistem yang dapat mengakomodir potensi-potensi yang dimiliki pada setiap karyawannya sehingga karyawan memiliki kesempatan karir yang baik, dihargai serta diakui potensi yang dimilikinya yang akan berdampak pada karyawan tersebut terikat terhadap pekerjaan dan perusahaan.

Komponen yang kedua yaitu individual motivation. Pengukuran individual motivation sebenarnya terdapat pada penilaian karya. PT X mempunyai 7 core competency, yang salah satunya mengenai drive. Asumsinya yaitu 
terdapat korelasi secara langsung antara drive (competency) dengan motivasi bekerja, yang berarti jika seseorang memiliki kompetensi drive yang tinggi maka secara langsung orang tersebut juga memiliki motivasi bekerja yang tinggi. Pada penilaian karya ada 3 bagian yang dijadikan bahan penilaian oleh atasan dan HC, yaitu proses kerja, result, dan leadership. Namun leadership ini hanya diberlakukan untuk atasan yang memiliki bawahan. Jadi point secara khusus untuk mengukur motivasi seseorang memang tidak ada dalam penilaian, akan tetapi hal tersebut akan terlihat dari proses kerja dan juga result nya. Seseorang yang menjalankan prosesnya dengan baik diasumsikan memiliki semangat bekerja yang baik, yang nantinya akan berdampak pada hasilnya. Karena dalam penilaian ini, hasil tidak mutlak menjadi tolak ukur utama keberhasilan seseorang, akan tetapi prosesnya pun memiliki bobot yang sama. Sehingga dalam penilaian proses ini akan terlihat motivasi bekerja seseorang dalam mencapai targetnya yang telah ditetapkan sebelumnya. Proses dalam berkerja juga menjadi pertimbangan yang sangat penting dalam menilai seseorang.

Menurut Anwar Prabu Mangkunegara (2008:61), "Motivasi merupakan kondisi atau energi yang menggerakkan diri karyawan yang terarah atau tertuju untuk mencapai tujuan organisasi perusahaan". Motivasi terbentuk dari sikap (attitude) karyawan dalam menghadapi situasi kerja di perusahaan. Sikap mental karyawan yng positif terhadap situasu kerja itulah yang memperkuat motivasi kerjanya untuk mencapau kinerja yang maksimal. Sikap mental karyawan haruslah memiliki sikap mental yang siap sedia secara psikofisik (siap secara mental, fisik, situasi, dan tujuan). Artinya, karyawan dalam bekerja secara mental siap, fisik sehat, memahami situasi, dan kondisi serta berusaha keras mencapai target kerja (tujuan utama organisasi).

Motivasi dalam berprestasi dapat diartikan sebagai suatu dorongan dalam diri seseorang untuk melakukan atau mengerjakan suatu kegiatan atau tugas dengan sebaik-baiknya agar mencapai prestasi dalam hal ini prestasi yang dituju tersebut dapat tetlihat dari hasil penilaian karya yang nantinya akan berdampak kepada reward yang akan didapatkan oleh karyawan tersebut.

Budaya organisasi adalah salah satu wujud angapan yang dimiliki, diterima secara implisit oleh kelompok dan menentukan bagaimana kelompok tersebut rasakan, pikirkan dan bereaksi terhadap lingkungannya yang beraneka ragam. Budaya organisasi mengacu ke suatu sistem makna bersama yang dianut anggotaanggota yang membedakan perusahaan itu terhadap perusahaan lain. Budaya organisasi juga merupakan sistem nilai organisasi yang dianut oleh anggota organisasi, yang kemudian mempengaruhi cara bekerja dan berperilaku dari para anggota organisasi.

Menurut Mayo (2000), budaya organisasi adalah faktor yang sangat penting dalam menciptakan human capital, faktor-faktor tersebut yaitu;

1) Melakukan penilaian atas kinerja baik dalam tim maupun perseorangan

Hal ini telah terimplementasi dan telah dijelaskan pada point sebelumnya yaitu melalui penilaian karya / penilaian kinerja yang dilakukan setiap 2 kali dalam 1 tahun. Penilaian karya yang dilakukan berdasarkan individual performance plan untuk individu. IPP dibuat oleh masing-masing karyawan yang nantinya akan diajukan kepada atasan. Namun untuk penilaian tim, hal tersebut mutlak dirancang dan dilaksanakan oleh Atasan. Biasanya untuk timtim yang berada dalam masing-masing departemen.

2) Melakukan penilaian terhadap karyawan dalam menghadapi masalah melalui proses pembelajaran dan perbaikan diri

Proses ini terutama dilakukan untuk karyawan baru yang mengikuti program Management Trainee. Disini karyawan yang merupakan karyawan baru yang unggulan, mendapatkan 
perilaku yang lebih intensif dengan perusahaan, agar mereka mengetahui bahwa perusahaan memikirkan dirinya, akan tetapi penilaian yang dilakukan juga lebih ketat. Mereka akan lebih sering menjalani konseling maupun mentoring hal ini agar bila terjadi suatu kesalahan proses pembelajaran dan perbaikan akan lebih dapat terkontrol oleh karyawan yang telah lebih dulu bekerja pada Asuransi Astra, biasanya tidak selalu Atasan langsung dari karyawan tersebut agar ilmu yang dimiliki akan semakin beragam. Penerimaan melalui program MT ini juga lebih selektif karena banyak program-program dan pembelajaran yang diterima oleh para karyawan MT yang nantinya diperuntukan untuk menduduki jabatan strategis perusahaan. Tentunya mereka harus selalu siap untuk menghadapi berbagai macam kondisi walaupun itu adalah masalah.

3) Menciptakan inovasi-inovasi baru dan kreativitas individu dinilai yang bertujuan untuk memperbaiki kondisi perusahaan

Disini juga jelas terlihat bahwa karyawan MT harus siap dalam berbagai kondisi walaupun itu suatu masalah karena dalam proses pemecahan masalah tersebut harus selalu ada improvementimprovement yang dilakukan.

4) Adanya dukungan dari perusahaan berupa adanya sarana dan prasarana yang lengkap bagi para karyawan dalam bekerja dan melaksanakan tugasnya.

Sarana dan prasarana yang disediakan telah cukup memadai dalam memfasilitasi dalam bekerja dan melaksanakan tugas. Berbagai macam klub informal pun juga ada pada Asuransi Astra agar para karyawannya jug adapat menyalurkan hobi-hobi nya.

5) Adanya transfer knowledge dari para senior kepada junior, saling berbagi pengalaman dalam bekerja.

Suasana kerja yang kondusif akan mendorong karyawan untuk memberikan kontribusi performa yang maksimum pada perusahaan. Karyawan yang merasa puas terhadap perusahaan tempat dia bekerja, kemungkinan besar akan memilih terus bekerja ditempat tersebut walaupun muncul peluang tawaran pekerjaan ditempat lain. Bila karyawan sudah mempunyai keterikatan yang kuat dengan perusahaan, maka akan terlihat dalam perilaku sehari-harinya dimana ia terdorong untuk melakukan sesuatu demi perkembangan perusahaan.

Salah satu komponen soft competency yang dibutuhkan perusahaan yaitu kemampuan bekerja dalam sebuah tim, sehingga semua karyawan dituntut untuk bisa bekerja dalam teamwork. Hal ini menjadi salah satu kriteria untuk merekrut karyawan baru. Perusahaan menyadari, dalam kondisi saat ini tidak cukup seseorang memiliki kemampuan individu yang baik saja, tetapi harus sudah berkembang ke arah kemampuan kerjasama tim yang baik. Menurut Widyastuti et.al (2008:23), efektifitas tim kerja didasarkan pada hasil-hasil produktif dan kepuasan pribadi. Kepuasan berkenaan dengan kemampuan tim untuk memenuhi kebutuhan pribadi para anggotanya dan kemudian mempertahankan keanggotaan serta komitmen mereka.

Menurut Tannebaum, Weschler and Nassarik (dalam Abdussalam 2008:18) kepemimpinan adalah pengaruh antar pribadi dalam situasi tertentu dan langsung melalui proses komunikasi untuk mencapai satu atau beberapa tujuan tertentu. Menurut Shared Goal, Hemhiel \& Coons dalam abdussalam 2008:20). Kepemimpinan adalah sikap pribadi yang memimpin pelaksanaan aktivitas untuk mencapai tujuan yang diinginkan.

Untuk posisi tertentu yang membutuhkan kemampuan untuk memimpin sebuah tim, diharapkan seseorang tersebut mempunyai kemampuan leaderhisip. Tidak setiap orang atau posisi membutuhkan kemampuan untuk memimpin sebuah tim. Jika pekerjaan yang memiliki karakteristik specialist tidak memerlukan leadership tetapi tetap efektif dan efisien dalam bekerja. Akan tetapi jika dalam 
karakteristik pekerjaan tersebut memiliki sifat leadership itu merupakan nilai tambah untuk karyawan tersebut, tetapi tidaklah menjadi masalah jika tidak memiliki sifat leadership karena perusahaan tidak menuntut untuk itu. Karena leadership yang dimaksudkan yaitu leadership untuk melaksanakan aktivitas untuk mencapai tujuan yang diinginkan.

\section{SIMPULAN}

Berdasarkan hasil penelitian dan pembahasan dapat ditarik kesimpulan sebagai berikut :

1. Menyadari pentingnya peran sumber daya manusia dalam kegiatan perusahaan, maka hendaknya perusahaan perlu mengelola sumber daya manusia sebaik mungkin karena kunci sukses suatu perusahaan bukan hanya pada keunggulan teknologi dan tersedianya dana, melainkan faktor manusianya.

2. Komponen human capital terdiri dari individual capability, individual motivation, the organization climate, workgroup effectiveness, dan leadership. Penerapan komponen human capital pada PT X belum optimal; artinya belum sesuai dengan pendekatan yang seharusnya, terutama pada aspek individual capability dan individual motivation.

\section{DAFTAR PUSTAKA}

Baron, Angela \& Amstrong Michael. (2007). Human Capital Management. United Kingdom: Kogan Page.

Edy, Sutrisno. 2010. Manajemen Sumber Daya Manusia: Jakarta, PT Prenada Media Group

Hariandja, Marihot Tua Efendi. 2002. Manajemen Sumber Daya Manusia : Pengadaan, Pengembangan, Pengkompensasian dan Peningkatan Produktivitas Pegawai. Grasindo Widiasarana Indonesia, Jakarta.

Hendrawan, Sanerya. 2012. Pengembangan Human Capital, Prespektif Nasional, Regional dan Global. Yogyakarta: Graha Ilmu.
Khatri, N. 2000. Managing human resources for competitive advantage. International Journal of Human Resource Management, 11:336.

Kreitner, R. dan A. Kinicki. 2005. Organizational Behaviour, 5th ed. Jilid 1, Jakarta: Mc Graw Hill.

Mayo, Andrew. 2000. "The Role of Employee Development in the Growth of Intellectual Capital, "Personal Review, Vol.29 No.4,2000,pp.521-533.

Mondy, Noe. 1990. Human Resouce Management. Massachusetts. New York

Nafukho, F.M., Hairston, N.R., Brooks, K., 2004. Human Capital theory: Implication for Human Resource Development. Human Resource Development International 7 (4), 545-551.

Sawarjuwono, T., dan A. P. Kadir. 2003. "Intellectual Capital: Perlakuan, pengukuran dan Pelaporan", Jurnal Akuntansi dan Keuangan Vol.5, No.1, Mei:35-57.

Setyanto, R. P., 2004. "Pengukuran Human Capital: Peluang bagi Departemen SDM untuk Berperan sebagai Strategic Business Partner", Usahawan, No.10, Tahun XXXIII, Januari:27-31.

Sugiyono. 2010. Memahami penelitian kualitatif. CV. ALFABETA: Bandung.

Totanan, C., 2004. "Peranan Intellectual Capital dalam Penciptaan Nilai untuk Keuggulan Bersaing", Usahawan, No.1, Tahun XXXIII, Januari: 27-31.

Unger, J.M., et al., 2009. Human Capital and Entrepreneurial success: A meta analytical review. Journal of business Venturing doi: 10.1016/j.jbusvent. 2009.04.004, pp.1-18. 